\title{
LILIN AROMATIK MINYAK ATSIRI KULIT BATANG KAYU MANIS (Cinnamomum burmannii) SEBAGAI REPELEN LALAT RUMAH (Musca domestica)
}

\author{
Prasetyorini Djarot $^{1 *}$, Moerfiah $^{1}$ dan Dwi Ambarwati ${ }^{2}$ \\ ${ }^{1}$ Program Studi Biologi, FMIPA-Universitas Pakuan \\ ${ }^{2}$ Program Studi Farmasi , FMIPA-Universitas Pakuan \\ "e-mail: prasetyorini@unpak.ac.id
}

diterima:20 Juni 2019; direvisi:26 Juli 2019; disetujui: 12 Agustus 2019

\begin{abstract}
ABSTRAK
Lalat rumah adalah jenis hewan yang banyak berperan sebagai vektor mekanis penyakit. Cara mengusir keberadaan lalat rumah yang dilakukan masyarakat sementara ini dinilai sangat kurang efektif, untuk itu perlu dibuat alternatif sediaan lain yang berguna untuk mengusir hinggapan lalat yang lebih baik dan nyaman. Beberapa penelitian menunjukkan bahwa beberapa minyak atsiri tumbuhan berpotensi sebagai repelen lalat rumah yang salah satunya adalah minyak atsiri kayu manis. Oleh karena itu perlu dilakukan penelitian yang bertujuan membuat sediaan lilin aromatik kulit batang kayu manis yang berpotensi sebagai repelent lalat rumah. Penyulingan minyak atsiri dilakukan dengan metode destilasi uap-air. Pembuatan lilin aromatik berbasis campuran parafin padat dan stearate (1:9) yang diperkaya dengan minyak atsiri dalam 5 formula, F1 (plasebo), F2 (fiksatif), F3 (1\% minyak atsiri), F4 (2\% minyak atsiri), F5 (3\% min), Uji daya tolak lalat dilakukan dengan menempatkan 20 ekor lalat dalam kandang berukuran 50x50x50 cm, didalamnya diberi nyala lilin aromatik yang mengandung minyak atsiri sesuai takaran. Pada jarak $15 \mathrm{~cm}$ dalam kandang juga ditempatkan kepala udang sebagai umpan. Parameter yang diamati adalah, jumlah hinggapan lalat setiap jam sampai jam ke 6 untuk setiap perlakuan, dan dihitung daya tolak lilin terhadap hinggapan lalat dan uji kesukaan. Hasil penelitian menunjukkan bahwa persen daya tolak lilin aromatic berturut-tururt dari yang paling kuat adalah lilin aromatik dengan konsentrasi minyak atsiri 3\% yaitu sebesar $89,72 \%$, lilin aromatik konsentrasi $2 \%$ sebesar $75,28 \%$, lilin aromatik konsentrasi $1 \%$ sebesar $68,06 \%$, fiksatif sebesar $49,17 \%$, sementara plasebo memiliki daya tolak yang paling rendah yaitu sebesar $9,72 \%$. Hasil uji kesukaan menunjukkan lilin aromatik minyak atsiri kulit batang kayu manis yang paling disukai adalah yg mengandung $2 \%$ minyak atsiri kayu manis.
\end{abstract}

Kata Kunci : Cinnamomum burmannii, lilin aromatik, Minyak atsiri, Musca domestica, repelensi

\section{AROMATIC CANDLE BARK ESSENTIAL OIL CINNAMON ROD (Cinnamomum burmannii) AS REPELEN FLIES HOUSE (Musca domestica)}

\section{ABSTRACT}

This research was aimed to create aromatic candle, infused with cinnamon (Cinnamomum burmanii) bark essential oil, which is a potential repellant for house fly (Musca domestica). The distillation of akar wangi samples was carried out at the Spice and Aromatic Research Unit by vapor distillation method for 9-12 hours. The aromatic candles were based on a mixture of solid paraffin and stearin in a 2:8 proportion, respectively, enriched with fragrant root bark essential oils with 5 formulas, namely F1 (placebo), F2 (fixative), F3 (1\% essential oil), F4 (2\% essential oil), and F5 (3\% essential oil). The repellency test was carried out by inserting 20 house flies in

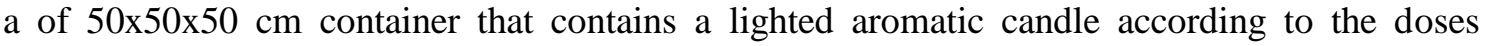
mentioned above, and shrimp scalps located $15 \mathrm{~cm}$ from the candle that functions as a bait. The 
calculated parameters were the hourly number of flies that were allured to the bait for 6 hours, which were related to the candle's repellency and the house fly's preference of candle. The repulsion ability result were $89.724 \%, 75.28 \%, 68.06 \%, 49.17 \%, 9.72 \%$ for F5, F4, F3, F2, and F1, respectively. The result also showed that the F4 sample was the most preferred sample.

Keywords: aromatic candle, Cinnamomum burmanni, Essential oils, fly repellency, Musca domestica.

\section{PENDAHULUAN}

Musca domestica atau lalat rumah atau sering disebut house fly merupakan salah satu spesies serangga yang banyak terdapat di seluruh dunia. Sebagian besar (95\%) dari berbagai jenis lalat yang dijumpai di sekitar rumah dan kandang. Di bidang kesehatan lalat rumah dianggap sebagai serangga pengganggu, karena selain merupakan vektor mekanis beberapa penyakit lalat ini juga mengganggu dari segi kebersihan dan ketenangan (Fotedar 2004 dan Moreira et all, 2000). Lalat rumah adalah spesies lalat yang banyak berperan sebagai vektor mekanis pada beberapa penyakit (Levine and Levine, 1991 dan Ferreira and Lacerda, 1993). Menurut Arroyo (1998), seekor lalat rumah dapat membawa lebih dari 100 macam organisme patogen yang dapat menyebabkan penyakit pada manusia dan hewan. Lalat rumah umumnya berkembang dalam jumlah besar pada tempat-tempat kotor dan sekitar kandang (Arroyo, 1998). Lalat rumah merupakan vektor mekanis jasad-jasad patogen yang membahayakan kesehatan bila hinggap dimakanan (DepKes RI, 2000).

Berbagai penyakit penting yang dapat ditularkan oleh lalat rumah antara lain penyakit viral seperti, poliomielitis, hepatitis, trakhoma, coxsackie dan infeksi ECHO virus. Berbagai jenis bakteri enteropatogen yang berhasil diisolasi dari $M$. domestica yang dikoleksi dari tempat sampah dan kandang ayam antara lain adalah Acinetobacter sp, Cirtobacter freundii, Enterobacter aerogenes, Enterobacter aggolerans, Escherichia coli, Hafnia alvei, Klebsiella pneumoniae, Morganella morganii, Proteus vulgaris, Pseudomonas sp dan Salmonella sp. (Amado et all, 2000). Graczyck et all.
(1999) menyatakan M. domestica juga berperan sebagai inang pembawa Staphylococcus sp dan Pseudomonas sp. Penyakit lambung dan usus (enterogastrik) pada manusia seperti bacillary disentri, salmonellosis (thypoid, parathypoid fever), enteritis, keracunan makanan dan cholera juga ditularkan oleh lalat rumah (Amado et all,2000).

Sigit et all, (2000), menyatakan pada beberapa kasus, lalat rumah juga bertindak sebagai vektor penyakit kulit seperti lepra dan yaws (frambusi atau patek) dan vektor untuk wabah sakit mata (epidemicconjunctivitis). $M$. domestica juga dilaporkan dapat membawa kista dari berbagai protozoa seperti Entamoeba histolytica, E. coli, Giardia intestinalis, Sarcocystis sp, Toxoplasmagondii, Isospora, Trichomonas sp dan beberapa telur cacing diantaranya cacing jarum atau cacing kremi (Enterobius vermicularis), cacing gilik (Ascaris lumbricoides) cacing kait (Ancylostoma dan Necator), cacing pita (Taenia, Dipylidium caninum), cacing cambuk (Trichuris trichiura), Toxocara canis dan Strongyloides stercoralis (Amado et all, 2000). Lalat rumah juga berperan sebagai vektor biologis cacing Habronema muscae (Sales et all, 2002). Penelitian adanya jamur pada lalat rumah didaerah kandang babi dan perkotaan diperoleh 10 jenis jamur, diantaranya ialah Aspergillus flavus, A. niger var niger, Penicillium corylophilum, P. fellutanum, Cladosporium cladosporoides, Fussarium sp. Alternaria alternate dan Curvularia brac. Mengingat bahayanya yang ditimbulkan oleh lalat, maka diperlukan mencari cara mengusir keberadaan lalat tersebut.

Cara-cara yang dilakukan masyarakat untuk mengusir keberadaan lalat rumah 
sementara ini diantaranya dengan menggunakan pengharum ruangan berbentuk spray, menggantungkan air di dalam kantong plastik berwarna putih dan menggunakan perangkap pelekat, namun hal tersebut dinilai kurang efektif mengusir lalat secara signifikan, untuk itu perlu dibuat alternatif sediaan lain yang berguna untuk mengusir hinggapan lalat.

Lilin yang pada awalnya hanya digunakan sebagai sumber penerangan, namun pada saat ini bisa digunakan sebagai alternatif dekorasi ruangan sekaligus memiliki fungsi ganda yaitu sebagai lilin aroma (lilin aromatik) juga berkhasiat sebagai penolak lalat dengan menambahkan minyak atsiri sebagai aroma lilin.

Kayu manis atau Cinnamomum burmannii merupakan salah satu tanaman yang kulit batang, cabang, dan dahannya dapat digunakan sebagai bahan rempahrempah dan merupakan salah satu komoditas ekspor indonesia (Susanti, 2003). Kandungan terbesar dari kayu manis adalah minyak atsiri yang mempunyai kandungan utama senyawa sinamaldehid $(60,72 \%)$, eugenol $(17,62 \%)$, dan kumarin $(13,39 \%)$ (Syahrizal, 2017). Kandungan senyawa aktif eugenol pada minyak atsiri kayu manis dapat berfungsi sebagai antioksidan dan antimikroba. Lukman dkk, (2013) menyatakan bahwa minyak atsiri kayu manis dapat digunakan juga sebagai repelan terhadap nyamuk $A$. aegepty pada konsentrasi $15 \%$ dan bubuk kayu manis dapat digunakan sebagai repelan terhadap lalat rumah (Syahrizal, 2017).

Mekanisme pengusir serangga dengan lilin aromatik minyak atsiri adalah melalui saluran pernafasan. Asap yang ditimbulkan dari lilin aromaterapi masuk ke dalam saluran pernapasan serangga melalui trachea dalam bentuk partikel mikro yang melayang di udara. Serangga akan menghindar bahkan mati bila menghirup partikel mikro tersebut dalam jumlah yang cukup (Novizan, 2002).

Berdasarkan uraian diatas, maka penulis melakukan penelitian yang bertujuan membuat lilin aromatik dengan penambahan minyak atsiri kulit batang kayu manis. Lilin aromatik tersebut diharapkan dapat digunakan untuk mengusir lalat.

\section{BAHAN DAN METODE Bahan dan Alat}

Bahan-bahan yang digunakan dalam penelitian ini adalah $2 \mathrm{Kg}$ kulit batang kayu manis kering berasal dari Balai Tanaman Rempah dan Aromatik Bogor, dan sudah dideterminasi di Pusat Konservasi Tumbuhan Kebun Raya Bogor dan diketahui bahwa tanaman yang digunakan merupakan tanaman kayu manis dengan nama latin Cinnamomum burmanii, yang termasuk dalam suku Lauraceae. Kulit batang kayu manis akan disuling dengan metode destilasi uap-air, lalat rumah, minyak nilam (pathcauli oil), parafin, stearin, pencetak lilin, pewarna lilin, sumbu dan umpan (kulit kepala udang) dan bahan lain.

Peralatan yang digunakan dalam penelitian ini adalah alat destilasi uap air, 5 buah kandang percobaan berukuran $50 \times 50 \times 50 \mathrm{~cm}$, stopwatch, timbangan analitik, alumunium foil, batang pengaduk, beaker glass, botol vial, botol cokelat, gelas ukur $50 \mathrm{ml}$ dan $100 \mathrm{ml}$, gelas cetakan, penangas air, penjepit kayu, pipet tetes dan alat gelas yang lainnya.

\section{Penyulingan Minyak Kayu Manis}

Penyulingan minyak atsiri dilakukan dengan metode penyulingan uap-air. Kulit batang kayu manis kering ditimbang $2 \mathrm{Kg}$, dirajang halus, lalu dimasukkan kedalam ketel penyulingan yang di bawah saringan sudah terisi air secukupnya, tutup rapat. Rangkaian alat dipasang kemudian uap air dialirkan melalui pendingin dan api dinyalakan. Uap air akan membawa minyak masuk ke dalam kondensor atau pendingin. Air dan minyak ditampung di separator panel atau corong pemisah, dipisahkan minyak dengan air menggunakan corong pemisah. Selanjutnya ditambahkan $\mathrm{Na}_{2} \mathrm{SO}_{4}$ anhidrat untuk menghilangkan gelembung-gelembung air pada fase 
minyak atsiri. Minyak atsiri disaring dengan kertas saring dan disimpan pada wadah yang gelap dan dibungkus dengan aliminium foil agar tidak rusak terkena paparan sinar matahari. Destilasi dilakukan selama 6-9 jam. Minyak atsiri kulit batang kayu manis yang diperoleh selanjutnya kandungan dan kadarnya diukur dengan metode GC MS.

\section{Karakteristik Minyak Atsiri Kulit Kayu Manis \\ Organoleptik Warna}

Karakterisasi minyak atsiri dilakukan untuk organoleptis warna dan aroma. Organoleptis warna dilakukan dengan dasar pengamatan visual menggunakan indra pengelihatan langsung terhadap minyak atsiri kayu manis. Pertama dipipet $2 \mathrm{ml}$ minyak atsiri kayu manis kemudian dimasukkan kedalam tabung reaksi diusahakan tidak ada gelembung udara. Disandarkan tabung reaksi berisi minyak kayu manis pada kertas atau karton berwarna putih. Diamati secara visual warna minyak atsiri kayu manis (Badan Standarisasi Nasional, 2006). Demikian juga untuk pengujian atau bau, pengujian ini dilakukan menggunakan indra penciuman langsung terhadap minyak kayu manis dengan menggunakan kertas uji/test paper (Badan Standarisasi Nasional, 2006).

\section{Formulasi Lilin Aromatik}

Minyak atsiri yang ditambahkan dalam pembuatan sediaan lilin aromatik tidak lebih dari $4 \%$, (Oppenheimer, 2001), oleh karena itu pembuatan lilin aromatik hanya menggunakan 3 konsentrasi minyak atsiri, yaitu: $1 \%, 2 \%, 3 \%$. Formula lilin aromatik yang dibuat ada 5, yaitu F1 (plasebo), F2 (fiksatif), F3 (ditambah minyak atsiri 1\%), F4 (ditambah minyak atsiri 2\%) dan F5 ((ditambah minyak atsiri 3\%). Sebagai fiksatif (zat pengikat) digunakan patchouli oil (minyak nilam) $0,1 \%$, parafin:stearin (1:9). Formula yang digunakan untuk membuat lilin aromatik dalam penelitian ini disajikan dalam Tabel 1.

Tabel 1. Formulasi Lilin Aromatik Minyak Atsiri Kulit Batang Kayu Manis

\begin{tabular}{lccccc}
\hline Komposisi Lilin & F1 (plasebo) & F2 (fiksatif) & F3 (1\%) & F4 (2\%) & F5 (3\%) \\
\hline Minyak atsiri $(\%)$ & 0 & 0 & 1 & 2 & 3 \\
Minyak nilam (mL) & 0 & 0,1 & 0.1 & 0.1 & 0,1 \\
Parafin (mL) & 10 & 9,59 & 9,89 & 9,79 & 9,69 \\
Stearin (mL) & 90 & 90,31 & 89,01 & 8.11 & 87,21 \\
\hline
\end{tabular}

F1: plasebo, F2: fiksatif, F3: Konsetrasi 1\%, F4: Konsentrasi 2\% dan F4: Konsetrasi 3\%.

\section{Pembuatan Lilin Aromatik}

Lilin dibuat dengan teknik cetak, basisnya menggunakan campuran parafin padat dan stearat dengan perbandingan 1:9. Pembuatan sumbu lilin dengan cara, parafin padat dicairkan secukupnya, kemudian sumbu dilapisi dengan lilin dengan cara mencelupkannya ke dalam lilin cair. Angkat dan biarkan sumbu mengering dengan cara direnggangkan.

Tahap pembuatan lilin dimulai dengan memanaskan stearin dan paraffin secara terpisah, selanjutnya dicampur 450 $\mathrm{mL}$ parafin cair dengan $50 \mathrm{~mL}$ stearin cair dalam beker glas pada suhu $80^{\circ} \mathrm{C}$ sambil diaduk rata. Selanjutnya dimasukkan minyak atsiri kulit batang kayu manis sesuai takaran $(1 \%, 2 \%$, dan 3\%) dan campur juga dengan $0,1 \mathrm{~mL}$ minyak nilam dan pewarna. Lilin cair selanjutnya dituang ke dalam cetakan $(100 \mathrm{~mL})$ yang masingmasing sudah diberi sumbu, kemudian dibiarkan sampai mengeras pada suhu ruangan, dan terbentuk lilin aromatik yang diinginkan (Murhananto dan Aryantasari, 2000).

\section{Uji Repelensi Lilin Terhadap Lalat Rumah (Musca domestica)}

Pengujian dilakukan di dalam kandang berukuran $50 \times 50 \times 50 \mathrm{~cm}$ yang pada setiap bagiannya ditutupi dengan kain 
batis dan disimpan dalam suhu ruang. Awalnya disiapkan 5 buah kandang, kandang ke-1, kandang ke-2, kandang k-3, kandang ke-4 dan kandang ke-5, masukan kedalam masing-masing kandang satu jenis lilin aromatik dengan formula yang berbeda (F1, F2, F3, F4 dan F5), selanjutnya lilin aromatik yang sudah ada dalam kandang dinyalakan, masukan umpan dan 20 ekor lalat rumah kedalam setiap kandang yang telah disiapkan. Selanjutnya hitung jumlah hinggapan lalat pada kandang ke-1, ke-2, ke-3, ke-4, dan ke-5 dicatat setiap jam mulai dari jam ke-1 sampai jam ke-6.
Dalam setiap jam dilakukan 3x pengusikan masing-masing 10 detik. Data jumlah hinggapan lalat yang telah diuji untuk setiap kandang baik untuk perlakuan lilin aromatik dengan konsentrasi minyak atsiri yang berbeda maupun waktu yang berbeda selanjutnya dianalisis untuk melihat efektivitas lilin aromatik dan efektivitas waktu terhadap kekuatan repelensi (daya tolak). Pengukuran daya tolak lilin terhadap jumlah lalat yang hinggap dapat dihitung dengan menggunakan rumus sebagai berikut:

$$
\text { Daya Tolak }=\frac{\text { Jumlah lalat sebelum perlakuan }- \text { Jumlah lalat setelah perlakuan }}{\text { Jumlah lalat sebelum perlakuan }} \times 100 \%
$$

\section{Uji Waktu Bakar Lilin Aromatik Minyak Kayu Manis}

Waktu bakar lilin adalah selang waktu yang menunjukkan daya tahan lilin dibakar sampai habis. Waktu bakar diperoleh dari selisih antara waktu awal pembakaran dan waktu saat sumbu lilin habis terbakar (api padam) (Raharja dkk, 2006).

\section{Uji Penerimaan Konsumen/Panelis}

Uji kesukaan/hedonic test, digunakan untuk menguji penerimaan konsumen terhadap lilin aromatik. Pengujian ini berupa penilaian atas warna dan aroma yang sebelumnya dibakar terlebih dahulu selama \pm 30 menit. Panelis terdiri dari 5 orang berjenis kelamin perempuan. Pada uji ini panelis dapat menentukan tingkat kesukaannya, adapun nilainya ialah sangat suka (3), suka (2), tidak suka (1).

Semua data yang diperoleh dalam penelitian ini diolah dengan menggunakan Rancangan Acak Lengkap pola faktorial $5 \times 6 \times 3$, selanjutnya jika perlakuan menunjukkan perbedaan yang nyata dilakukan uji lanjut Duncan untuk mengetahui konsentrasi minyak atsiri kulit batang kayu manis dalam lilin aromatik yang paling memberikan pengaruh sebagai penolak/ pengusir lalat (Notoatmodjo, 2012).

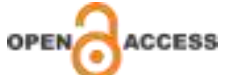

\section{HASIL DAN PEMBAHASAN \\ Hasil Penyulingan Minyak Atsiri Kulit Batang Kayu Manis}

Hasil penyulingan $2 \mathrm{Kg}$ kulit batang kayu manis kering dengan metode uap-air, menghasilkan $11 \mathrm{~mL}$ minyak atsiri (rendemen 0,55\%). Pada umumnya dalam penyulingan minyak atsiri kulit batang kayu manis dengan metode yang sama adalah berkisar antara 0,3\%-1\%. Hasil penyulingan minyak atsiri ditentukan oleh beberapa faktor, yang pertama adalah ukuran bahan (makin kecil ukuran bahan makin tinggi rendemennya), daerah asal atau tempat tumbuh, waktu panen, waktu penyulingan (Guenther, 1987). Penyulingan dengan metode uap-air ini merupakan metode penyulingan dengan tekanan uap jenuh yang rendah karena suhu uap jenuh yang digunakan maka kerusakan minyak lebih kecil, selain itu ciri khas dari metode ini yaitu uap selalu dalam keadaan basah, jenuh dan tidak terlalu panas sehingga bahan yang disuling hanya berhubungan dengan uap dan tidak dengan air panas.

Minyak atsiri hasil penyulingan berwarna kuning dan beraroma khas kayu manis. Hasil karakteristik dapat dilihat pada Tabel 2. 
Tabel 2. Karakteristik Minyak Atsiri Kulit Batang Kayu Manis

\begin{tabular}{ccc}
\hline No & Jenis Pengujian / Karakteristik & Hasil Pengujian Karakteristik \\
\hline 1 & Warna & Kuning \\
2 & Aroma & Khas kayu manis \\
\hline
\end{tabular}

Pengujian warna minyak atsiri kulit batang kayu manis dilakukan secara visual dan menunjukan warna kuning, hasil ini sesuai menurut Syarief dan Anies (1998) dalam Sihite (2009) yang menyatakan bahwa minyak atsiri yang baru diekstrak biasanya tidak berwarna atau berwarna kekuningan, tapi ada juga beberapa minyak berwarna kemerah-merahan, hijau, coklat dan biru, dan aroma minyak atsiri kayu manis dilakukan menggunakan indra penciuman dan tercium khas minyak kayu manis.

\section{Hasil Penentuan Kandungan Minyak Atsiri Kulit Batang Kayu Manis}

Hasil analisis minyak atsiri kulit batang kayu manis (oleum foeniculi) dari BALITRO menggunakan GC-MS terdapat 14 senyawa yang terkandung di dalamnya. Hasil yang diperoleh sesuai dengan literatur yang menyatakan bahwa terdapat beberapa kandungan utama yang dapat bekerja sebagai penolak lalat diantaranya yaitu sinamaldehid $(47,57 \%)$, eugenol $(4,05 \%)$, myristicin $(1,28 \%)$. Hasil analisis dengan GC MS kandungan senyawa pada minyak atsiri kulit batang kayu manis disajikan dalam Tabel 3.

Tabel 3. Kandungan Senyawa Minyak Atsiri Cinnamomum burmanii

\begin{tabular}{ccccc}
\hline No & R. time & Quality & Senyawa & Kandungan $(\%)$ \\
\hline 1 & 7.482 & 94 & 1-Phelandrene & 1,26 \\
2 & 7,911 & 96 & -alpha.-terpinene & 1,51 \\
3 & 8,863 & 94 & -beta,-Phelandrene & 4,35 \\
4 & 11,044 & 96 & o-Cymene & 1,26 \\
5 & 24,573 & 94 & .alpha-Terpinolene & 1,65 \\
6 & 28,0054 & 97 & Trans-Caryophyllene & 3,75 \\
7 & 28.078 & 99 & Caryophyllene & 4,21 \\
8 & 32.449 & 83 & Champene (CAS) & 1,19 \\
9 & 48.059 & 98 & Cinnamaldehyde & 47,57 \\
10 & 49,092 & 98 & Gamma-sitosterol & 1,60 \\
11 & 49.426 & 99 & Gamma-sitosterol & 6,92 \\
12 & 49811 & 97 & Cinnamyl acetate & 15,15 \\
13 & 50.026 & 98 & Eugenol & 4,05 \\
14 & 51,478 & 99 & Myristin & 1,28 \\
\hline
\end{tabular}

Dari beberapa kandungan senyawa kimia yang terdapat dalam minyak atsiri kulit batang kayu manis, komponen yang utama yang memiliki efek sebagai penolak lalat adalah sinamaldehid, eugenol dan myristin yang dapat menimbulkan aroma yang khas. Daya kerja lilin bersifat sebagai daya tolak dan tidak mematikan sehingga serangga tidak menyenangi racun yang bersifat reppelen ini dapat secepatnya menghindari sasaran walaupun sudah diberi umpan. Dari hasil uji GC-MC minyak atsiri kulit batang kayu manis, kandungan terbesarnya adalah sinamaldehid yaitu mencapai $47,57 \%$ dibandingkan senyawa minyak atsiri lainnya. Zat tersebut akan mengganggu reseptor yang terdapat pada antena serangga sehingga menimbulkan efek reppelan terhadap serangga tersebut, dengan demikian serangga akan menghindar bila menghirup aroma minyak atsiri dalam jumlah yang cukup, adanya senyawa sinamalaldehid di dalam minyak kayu manis memberikan 
hasil daya tolak lalat rumah yang efektif.

\section{Hasil Pembuatan Lilin Aromatik}

Untuk menambah daya tarik, dalam pembuatan lilin aromatik diberi pewarna. Pemberian pewarna tersebut dilakukan pada saat semua bahan telah mencair dan siap dituangkan dalam pencetak lilin. Selanjutnya hasil pembuatan lilin aromatik dikarakterisasi. Hasil karakterisasi disajikan pada Tabel 4. Dan gambar lilin aromatik disajikan pada Gambar 1

Tabel 4. Hasil Karakterisasi Lilin Aromatik Minyak Atsiri Kayu Manis

\begin{tabular}{cccl}
\hline No & Konsentrasi minyak atsiri & Warna & \multicolumn{1}{c}{ Aroma } \\
\hline 1 & F1 (plasebo) & Orange & Tidak berbau \\
2 & F2(fiksatif) & Merah & Khas aromatik Nilam \\
3 & F3 $(1 \%+$ fiksatif $)$ & Biru & Khas aromatik kayu manis \\
4 & F4 $(2 \%+$ fiksatif $)$ & Coklat & Khas aromatik Kayu manis \\
5 & F5 $(3 \%+$ fiksatif $)$ & Hijau & Khas aromatik kayu manis \\
\hline
\end{tabular}

\section{Hasil Pengujian Repelensi Lilin Aromatik Terhadap Lalat Musca domestica}

Hasil pengujian repelensi menunjukkan daya batang kayu manis terhadap lalat $M$. domestica berbeda sangat nyata. Rata-rata daya tolak lilin aromatik terhadap $M$ domestika disajikan dalam Tabel 4. tolak lilin aromatik minyak atsiri kulit

Tabel 5. Daya tolak lilin aromatik minyak atsiri C. burmanii terhadap M. domestica

\begin{tabular}{ccccccc}
\hline \multirow{2}{*}{ Jam-ke } & \multicolumn{5}{c}{ \% Daya tolak lilin aromatik } & \multirow{2}{*}{ Rata-rata } \\
\cline { 2 - 5 } & F1(plasebo) & F2 (fiksatif) & F1 $(1 \%)$ & F2(2\%) & F3(3\%) & \\
\hline 1 & 8,33 & 48,33 & 68,33 & 86,67 & 88,33 & $59,00 \pm 28,89^{\mathrm{b}}$ \\
2 & 13,33 & 53,33 & 71,67 & 80,00 & 93,33 & $62,33 \pm 28,84^{\mathrm{a}}$ \\
3 & 8,33 & 51,67 & 71,67 & 76,67 & 96,67 & $61,00 \pm 31,18^{\text {ab }}$ \\
4 & 10,00 & 51,67 & 71,67 & 70,00 & 90,00 & $60,00 \pm 29,15^{\text {ab }}$ \\
5 & 10,00 & 46,67 & 63,33 & 66,67 & 86,67 & $56,00 \pm 25,86^{\mathrm{c}}$ \\
6 & 8,33 & 43,33 & 61,67 & 75,28 & 89,72 & $52,67 \pm 26,72^{\mathrm{d}}$ \\
Rata-rata & $9,72^{\mathrm{a}}$ & $49,17^{\mathrm{d}}$ & $68,06^{\mathrm{c}}$ & $75,28^{\mathrm{b}}$ & $89,72^{\mathrm{a}}$ & \\
\hline
\end{tabular}

Angka yang diikuti oleh huruf yang sama dalam lajur atau kolom yang sama menunjukkan tidak berbeda nyata.

Dalam Tabel 5 terlihat makin tinggi konsentrasi minyak atsiri sampai batas $3 \%$ dalam lilin aromatik makin kuat daya tolak lilin aromatik terhadap $M$ domestika. Demikian juga dengan waktu, waktu berpengaruh sangat nyata terhadap daya tolak $M$ domestika, waktu yang paling kuat daya tolaknya adalah jam ke-2, ke-3 dan ke-4, selanjutnya makin lama waktu nyala lilin aromatik secara nyata menurunkan daya tolak terhadap nyamuk $M$ domestika.

Persentase daya tolak lilin aromatik terhadap lalat $M$. domestica tertinggi yaitu terdapat pada lilin aromatik formula 5 (3\%) yaitu sebesar $89,72 \%$, formula 4 (2\%) memiliki daya tolak sebesar 75,28\%, formula $3(1 \%)$ memiliki daya tolak sebesar $68,06 \%$, formula 2 (minyak nilam) memiliki daya tolak sebesar $49,17 \%$, sedangkan, formula I plasebo memiliki daya tolak yang paling rendah yaitu $9,72 \%$, hal ini bisa dimengerti karena plasebo merupakan lilin yang tidak ditambahkan minyak atsiri. Minyak atsiri daun nilam yang berfungsi sebagai fiksatif juga ternyata secara nyata meningkatkan daya tolak nyamuk rumah dibandingkan dengan kontrol. Turunya daya tolak pada jan ke-6, ini bisa dipahami karena, minyak atsiri sifatnya mudah menguap sehingga setelah jam ke 6 kandungan minyak atsiri dalan lilin aromatik jauh berkurang, dan ini 
menyebabkan daya tolaknya terhadap lalat rumah juga berkurang.

Sediaan repelan dianggap efektif apabila memiliki daya tolak lebih dari $70 \%$ selama \pm 6 jam (Kardinan, 2004). Lilin aromatik sebagai penolak lalat menunjukan bahwa formula 3\% memiliki daya tolak cukup baik dan mengalami kenaikan dari jam ke-1 sampai jam ke-3 yaitu $88,33 \%, 93,33 \%$ dan $96,67 \%$ dan selanjutnya mengalami penurunan pada jam ke-4 sampai ke 6 (Tabel 4), Striabutra dan Sonwera (2013) menjelaskan bahwa efektivitas reppelen dapat meningkat karena kandungan senyawa di dalamnya dan zat pembawanya. Lilin aromatik selain digunakan sebagai pengusir lalat juga dapat digunakan sebagai aromatik karena aroma yang dihasilkan sangat disukai sehingga memberikan rasa segar dan nyaman bernuansa alami.

\section{Hasil Uji Kesukaan}

Hasil uji kesukaan terhadap aroma lilin aromatik menggunakan metode Friedman memberikan pengaruh yang sama terhadap aroma (Sig 0,294 > 0,05). Berdasarkan hasil analisa diketahui bahwa formula lilin aromatik dengan minyak atsiri kulit batang kayu konsentrasi 2\% merupakan formula yang memiliki aroma paling banyak disukai oleh panelis dengan nilai rata-rata peringkat sebesar 2,23\% dibandingkan dengan formula yang lain. Hal ini dikarenakan pada formula $2 \%$ memberikan aroma yang cukup harum dan tidak terlalu menyengat aromanya, 1 .Hasil analisis uji kesukaan ditampilkan pada Gambar 1.

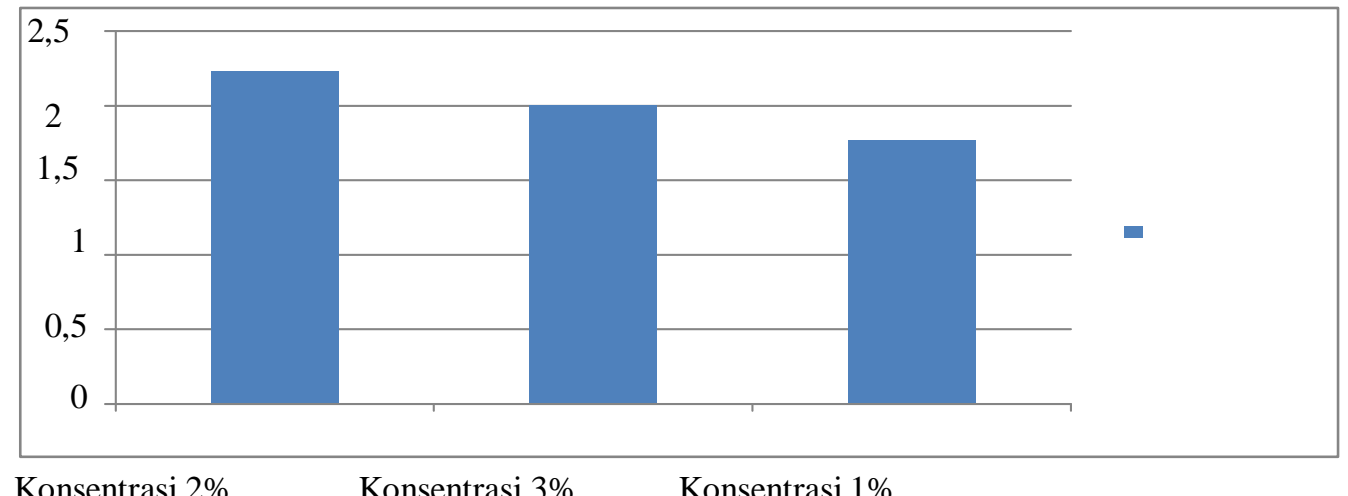

Konsentrasi 2\% Konsentrasi 3\% $\quad$ Konsentrasi 1\%

Gambar 1. Diagran Batang Nilai Rata-Rata Uji Penerimaan Panelis Terhadap Aroma dari Lilin Aromatik Minyak Kayu Manis.

Dari hasil analisis uji kesukaan terhadap warna lilin aromatik menggunakan metode Friedman memberikan pengaruh yang sama terhadap warna (Sig 0,206 > 0,05). Berdasarkan hasil analisa data uji hedonic bahwa F2 (fiksatif) merupakan formula yang memiliki warna paling disukai, formula 2 merupakan formula dengan penambahan warna biru terang dengan nilai rata-rata sebesar $2,25 \%$ dibandingkan F4 (2\%) memiliki nilai rata-rata $1,75 \%$ dengan warna coklat dan F5 (3\%) warna hijau muda memiliki nilai rata-rata $2 \%$. Hasil analisis uji kesukaan terhadap warna ditampilkan pada Gambar 2. 




Gambar 2. Diagram Batang Nilai Rata-Rata Uji Penerimaan Panelis Terhadap Warna Lilin Aromatik Minyak Kulit batang Kayu Manis.

\section{Hasil Uji Bakar}

Menurut Rahardja dkk (2006) waktu bakar yang terbaik adalah lilin dengan campuran parafin dan stearin dengan perbandingan 1:9. Hasil penelitian menunjukkan waktu bakar lilin selama 9 jam 28 menit F2 (fiksatif), 9 jam 10 menit F1 (plasebo), 8 jam 50 menit F3 (1\%), 8 jam 42 menit F4 (2\%) dan 8 jam 40 menit F5 (3\%). Makin tinggi kandungan minyak atsiri lilin aromatik memiliki waktu bakar yang lebih cepat. Menurut Murhananto dan Aryantasari (2000), lama bakar lilin selain dari konsentrasi bahan aktif juga ditentukan oleh ukuran dan letak sumbu. Makin besar ukuran sumbu atau makin kepinggir letak sumbu lilin makin cepat habis.

\section{KESIMPULAN}

1. Lilin aromatik minyak atsiri kulit batang kayu manis efektif digunakan sebagai penolak lalat rumah.

2. Konsentrasi minyak kayu manis yang memiliki daya tolak lalat paling efektif yaitu pada konsentrasi 3\% dengan nilai rata-rata daya tolak sebesar $89,72 \%$.

3. Daya terima panelis terhadap aroma yang paling disukai yaitu pada konsentrasi $2 \%$ dengan nilai rata-rata peringkat sebesar 2,23\% dan warna pada sediaan lilin aromatik yang disukai yaitu pada konsentrasi $1 \%$ dengan nilai rata-rata peringkat sebesar $2,25 \%$.

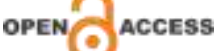

\section{DAFTAR PUSTAKA}

Amado S, CG Gomes and EMVM Azevedo. (2000). Longevity of Musca domestica L. (Diptera: Muscidae) Parasitized by Habronema muscae Carter (Nematoda: Habronematidae). Parasitol. Dav. 24:12.

Arroyo HS. (1998). Distribution and Importance-Life Cycle and descriptinDamage-Economic Injury LevelManagement-selected references. Univ. of Florida Institute of Food and Agricultural Sciences. Depart.of Entomology Nematology. http://www.house flyMusca_domestica-Linnaeus.htm.

Badan Standardisasi Nasional (2006). Keputusan Kerala Badan Standardisasi Nasional Nowior: 72/Kep/Bsn/2/2006

Depkes RI. (2000). Prinsip-prinsip Higiene dan Sanitasi Makanan. Depkes RI. Jakarta.

Ferreira MJM and PV Lacerda. (1993). Muscoides sinantropiscos associados ao lixo urbano em goiania, GO. Rev. Bras. Zool. 10: 185-195.

Fotedar R. Vector. (2000). Potensial of Houseflies (M. domestica) in Tranmission of Vibrio cholera in India. Acta Tropica. 78 (220): 31-34.

Graczyk TK, MR Cranfield, F Ronal and H Bixler. (1999). House Flies (MUSCA DOMESTICA) as transport host of 
CRYPSTOSPORIDIUM PARVUM. Am. J. Trop. Med. Hyg. 61(3): 500-504. Guenther, E. (2006). Minyak Atsiri. Jilid 1. Penerjemah Ketaren S. Penerbit UI Press

Kardinan, A. (2004). Tanaman Pengusir dan Pembasmi Nyamuk. Jurnal Ilmiah Pertanian. Edisi ketiga. Vol 3. No 4. Agromedia Pustaka. Jakarta.

Levine OS and M MLevine. (1991). Houseflies (Musca domestica) as mechanical vector of shigellosis. Infect. Immun. 1991; 31: 445-452.

Lukman, Y., Sulianti, SB., dan Oktaviana, R. (2013). Formulasi Gel Minyak Kulit Kayu Manis (Cinnamomum burmannii) Sebagai Sediaan Anti Nyamuk. Jurnal Penelitian Farmasi Indonesia

Murhananto dan R. Aryasatyani. (2000). Membuat dan Mendekoras lilin. Puspa Swara, Jakarta

Moreira CK, M de L Capurro, M Walter, E Pavlova, H Biessmann, AA James, AG deBianchi and O Marinotti. (2004). Primary characterization and basal promoter activity of two hexamerin genes of $\mathrm{M}$. domestica. J. of Insect Science. 4: 2.

Novizan (2002) Membuat dan memanfaatkan pestisida ramah lingkungan. Agro Media Pustaka. Jakarta

Notoatmodjo,S. (2012). Metodologi Penelitian Kesehatan. Jakarta: Rineka Cipta.

Oppenheimer, B. (2001). The Candlemaker's Companion. Storey Books. Massachusetts USA

Sales MSN, GL Costa and VREP Bittencourt. (2002). Isolation of Fungi in Musca domestica Linnaeus, 1758 (Diptera: muscidae) Captured at Two Natural Breeding Ground in the Municipality of seropedica, Rio de Janeiro, Brazil. Mem inst Oswaldo Cruz, rio de Janeiro. 97 (8): 1107-1110

Sihite, D. T. 2009. Karakteristik minyak atsiri jeringau (Acorus calamus). Skripsi. Fakultas Pertanian Universitas Sumatera Utara. Medan.

Sigit HS, FX Koesharto, UK Hadi, DJ Gunandini dan S Soviana. (2006). Hama Pemukiman Indonesia, Pengenalan, Biologi dan Pengendalian. Unit Kajian Pengendalian Hama Permukiman (UKPHP), Fakultas Kedokteran Hewan IPB.

Susanti, N,IM., Gandidi, MD., dan Susila, ES. (2013). Potensi Produksi Minyak Atsiri dari Limbah Kulit Kayu Manis Pasca Panen. Jurnal FEMA. 1(2). 4549.

Syahrizal. (2017). Pemanfaatan Kayu Manis (Cinnamomum veru) Sebagai Bioinsektisida Alami untuk Mengusir Lalat Rumah (Musca domestica). Vol, 10. No, 1. Poltekkes Kemenkes Aceh. Aceh

Rahardja.S., Setyaningsih D., Doris M.S.T. (2006). Pengaruh Perbedaan Komposisi Bahan, Konsentrasi dan Jenis Minyak Atsiri pada Pembuatan Lilin Aromaterapi. IPB. Bogor.

Striabutra, D. Dan Sonwera, M. (2013). Reppelent Activity of Herbal Essential OilsAgaints Aedes aegypty (Lin) and Culex quinquefasciatus (Say), Asian Pasific Journal of Tropical Disease 